Volume 1 Nomor 1, Februari 2016, halaman 1-13

\title{
MEREDUKSI KECEMASAN MATEMATIKA SISWA SMP MELALUI IMPLEMENTASI COOPERATIVE LEARNING TIPE GROUP INVESTIGATION
}

\author{
Ahmad Dzulfikar \\ Universitas Pesantren Tinggi Darul ‘Ulum, dzulfikara@yahoo.co.id
}

\begin{abstract}
ABSTRAK
Penelitian ini merupakan studi kuasi eksperimen dengan The Post-test Only Non-Equivalent Group Design. Penelitian ini bertujuan untuk menginvestigasi perbedaan kecemasan matematika pada siswa yang diberi perlakuan berupa Cooperative Learning Tipe Group Investigation dan pembelajaran konvensional. Instrumen yang digunakan dalam penelitian ini berupa skala kecemasan matematika siswa dan jurnal harian siswa. Penelitian ini menemukan bahwa tidak terdapat perbedaan kecemasan matematika siswa pada kedua kelas. Akan tetapi, hasil analisis terhadap jurnal harian siswa menunjukkan bahwa kecemasan matematika siswa yang diberi perlakuan berupa Cooperative Learning Tipe Group Investigation menunjukkan tren penurunan jika dibandingkan dengan kecemasan matematika siswa kelas konvensional yang cenderung fluktuatif. Oleh karena itu, penelitian lebih lanjut diperlukan untuk mengkaji efek Cooperative Learning Tipe Group Investigation terhadap kecemasan matematika siswa.
\end{abstract}

Kata Kunci: Kecemasan Matematika, GI, Cooperative Learning Tipe Group Investigation.

\section{ABSTRACT}

This study was a Quasi Experiment: The Post-test Only NonEquivalent Group Design. This study aimed to investigate the differences in students' math anxiety was treated Cooperative Learning of the Group Investigation Type and conventional learning. The instruments used in this study were math anxiety scale and students' daily journal. This study resulted in the finding that there was no difference of students' math anxiety in both classes. However, judging from the students' daily journal, students' math anxiety of Cooperative Learning of the Group Investigation Type class showed a downward trend compared to the conventional class students tend to fluctuate. Therefore, further research is needed to investigate the effect of Cooperative Learning of the Group Investigation Type on students' math anxiety.

Keywords: Math Anxiety, GI, Cooperative Learning of The Group Investigation Type.

How to Cite: Dzulfikar, A. (2016). Mereduksi Kecemasan Matematika Siswa SMP Melalui Implementasi Cooperative Learning Tipe Group Investigation. Mathline: Jurnal Matematika dan Pendidikan Matematika, Vol.1, No.1, 1-13. 


\section{PENDAHULUAN}

Pemahaman terhadap domain kognitif dan afektif pada pendidikan matematika menjadi arah penting menuju peningkatan kualitas pendidikan matematika secara umum (Gleason, 2008). Hal ini dikarenakan, baik secara langsung maupun tidak langsung, domain afektif pada diri seseorang berpengaruh terhadap domain kognitifnya. Salah satu domain afektif pada pendidikan matematika adalah kecemasan matematika.

Kecemasan matematika tergolong sebagai state anxiety (Erdogan, Kesici, \& Sahin, 2011), yaitu kecemasan yang muncul pada situasi-situasi spesifik. Hal ini dikarenakan gejala kecemasan matematika muncul pada situasi atau kondisi tertentu, misalnya ketika seseorang belajar atau menghadapi tes matematika. Kecemasan matematika diartikan sebagai perasaan tidak nyaman pada diri seseorang yang muncul ketika menghadapi permasalahan matematika (Ma, 2003) yang berhubungan dengan perasaan takut dan khawatir dalam menghadapi situasi spesifik yang berkaitan dengan matematika (D'Ailly \& Arth, dalam Khatoon \& Mahmood, 2010). Oleh karena itu, kecemasan matematika dalam hal ini didefinisikan sebagai bentuk kecemasan yang dialami siswa ketika belajar, mengerjakan tugas, atau tes matematika.

Meece et al. (1990), Sherman \& Wither (2003), Karimi \& Venkatesan (2009), dan Khatoon \& Mahmood (2010) menemukan kaitan erat dan korelasi negatif antara kecemasan dan performance serta achievement matematika siswa. Hal ini juga didukung hasil penelitian Zakaria \& Nordin (2008) dan Erdogan, Kesici, \& Sahin (2011) yang menyatakan bahwa kecemasan matematika yang tinggi berpengaruh secara signifikan terhadap rendahnya pretasi belajar siswa. Selain itu, kecemasan matematika juga menjadi penyebab paling signifikan yang dapat menghalangi prestasi belajar matematika siswa dan juga berpengaruh secara signifikan terhadap motivasi.

Lebih lanjut, kecemasan matematika pada tingkat tertentu dapat berpengaruh pada kondisi tubuh seseorang. Hasil penelitian Lyons \& Beilock (2012) menunjukkan bahwa masalah-masalah matematis dapat membuat bagian otak, yaitu insula posterior mempersepsikan rasa sakit pada diri seseorang. Dengan kata lain, kecemasan matematika memiliki pengaruh yang sama dengan rasa sakit yang dialami oleh tubuh yang disebabkan oleh sebab-sebab yang lain.

Hasil penelitian Renga \& Dalla menunjukkan bahwa siswa SD umumnya memiliki sikap positif terhadap matematika, tetapi kecemasan matematika mereka 
meningkat ketika memasuki jenjang SMP dan SMA (Herman, 2005). Hal ini berbanding lurus dengan meningkatnya kompleksitas materi matematika yang harus mereka pelajari. Oleh karena itu, untuk dapat menjawab setiap tantangan dalam pembelajaran matematika, siswa membutuhkan motivasi yang lebih besar dan rasa percaya diri yang lebih tinggi pula. Sejalan dengan hasil penelitian tersebut, beberapa hasil penelitian yang dirangkum oleh Khatoon \& Mahmood (2010) mengungkapkan bahwa kecemasan matematika ditemukan pada siswa sekolah dasar, sekolah menengah, hingga jenjang perguruan tinggi.

Dari uraian tersebut diketahui bahwa penting untuk mengurangi kecemasan matematika siswa sejak dini agar prestasi belajar matematika mereka tidak terhambat. Blazer (Yandi, 2013) memberikan beberapa rekomendasi untuk mengurangi kecemasan matematika siswa yaitu dengan mengembangkan kemampuan dan sikap positif mereka terhadap matematika, menghubungkan matematika dengan kehidupan, meningkatkan cara berpikir kritis, dan mengembangkan pembelajaran aktif. Sementara itu, Woodard (2004) memberikan rekomendasi adalah dengan mengimplementasikan pembelajaran berkelompok, hal ini dimaksudkan agar membantu siswa memahami bahwa temantemannya juga menghadapi masalah atau kesulitan yang sama dalam matematika. Salah satu bentuk pembelajaran berkelompok adalah Cooperative Learning Tipe Group Investigation (CLGI). Pembelajaran ini menciptakan interaksi dan ketergantungan positif di antara siswa dan suasana menyenangkan selama pembelajaran sehingga siswa tidak merasa bosan dan cemas selama pembelajaran. Apabila pada proses diskusi siswa mengalami hambatan, guru dapat memberikan sedikit bantuan, atau yang Vygotsky sebut sebagai scaffolding. Dengan scaffolding, guru memberikan bantuan secukupnya kepada siswa melalui serangkaian pertanyaan guna menggali dan mengarahkan siswa kepada jawaban yang dituju. Pemberian scaffolding ini dapat diiringi dengan pemberian persuasi untuk mereduksi kecemasan matematika siswa.

Dalam penelitian ini, peneliti memberikan solusi alternatif bahwa salah satu model pembelajaran yang dapat menunjang keterlibatan siswa dalam pembelajaran, menghubungkan matematika dengan kehidupan, meningkatkan cara berpikir kritis, menyediakan dukungan dan penguatan sebagaimana rekomendasi-rekomendasi tersebut adalah model CLGI. 
Penelitian ini mengkaji pengaruh CLGI sebagai pembelajaran alternatif untuk mereduksi kecemasan matematika. Melalui implementasi pembelajaran ini diharapkan kecemasan matematika siswa dapat direduksi. Dari uraian tersebut, peneliti menduga bahwa:

1. kecemasan matematika siswa SMP yang diajar dengan CLGI lebih rendah daripada kecemasan matematika siswa SMP yang diajar dengan pembelajaran kovensional,

2. ditinjau dari aspek kecemasan matematika ketika siswa belajar di kelas matematika, kecemasan matematika siswa SMP yang diajar dengan CLGI lebih rendah daripada kecemasan matematika siswa SMP yang diajar dengan pembelajaran kovensional, dan

3. ditinjau dari aspek kecemasan matematika ketika siswa menghadapi tes matematika, kecemasan matematika siswa SMP yang diajar dengan CLGI lebih rendah daripada kecemasan matematika siswa SMP yang diajar dengan pembelajaran kovensional.

\section{METODE PENELITIAN}

Desain pada penelitian ini adalah A Quasi-Experimental Design: The Post-test Only Non-Equivalent Group Design. Penelitian ini dilaksanakan di salah satu SMP di kota Bandung, pada semester genap tahun ajaran 2013/2014. Dalam penelitian ini yang menjadi populasi adalah seluruh siswa kelas VIII di SMP tersebut. Sampel yang diambil dalam penelitian ini adalah sekelompok siswa yang terhimpun dalam satu kelas dengan ketentuan satu kelas kontrol dan satu kelas eksperimen. Kelas eksperimen diberi perlakuan berupa CLGI, sedangkan kelas kontrol dengan pembelajaran konvensional. Pengambilan sampel pada penelitian ini tidak memungkinkan untuk dilakukan acak murni. Oleh karena itu, dalam penelitian ini pengambilan sampel dilakukan dengan teknik purposive sampling. Sampel dalam penelitian ini adalah kelas VIIIA dan VIIIC, hal ini didasarkan dari pertimbangan guru matematika di sekolah tersebut bahwa secara karakteristik kedua kelas relatif tidak berbeda. Penentuan kelas eksperimen dan kelas kontrol ditentukan dengan randomisasi terhadap dua kelas tersebut.

Untuk mengukur tingkat kecemasan matematika siswa juga digunakan skala Likert yang dimodifikasi. Jawaban dari pernyataan skala likert dalam penelitian ini terdiri dari empat opsi, yaitu sangat setuju, setuju, tidak setuju, dan sangat tidak setuju. 
Cooke, Cavanagh, Hurst, \& Sparrow (2011) menyatakan bahwa kecemasan matematika seseorang dapat diidentifikasi dari 4 domain, yaitu mathematics knowledge/understanding, somatic, cognitive, dan attitude. Mathematics knowledge/understanding terkait munculnya pikiran bahwa ia tidak cukup paham tentang matematika. Somatic terkait perubahan pada keadaan tubuh seseorang, misalnya berkeringat atau jantung berdebar cepat. Cognitive terkait perubahan kognitif seseorang ketika berhadapan dengan matematika, misalnya tidak dapat berpikir jernih atau menjadi lupa hal-hal yang biasanya ia ingat. Attitude terkait sikap yang muncul ketika seseorang berhadapan dengan matematika, misalnya ia tidak percaya diri untuk menyelesaikan tugas atau permasalahan matematika yang diminta atau enggan untuk melakukannya. Keempat domain ini dalam penelitian ini menjadi indikator untuk mengukur kecemasan matematika siswa.

Skala kecemasan matematika yang digunakan dalam penelitian ini adalah hasil adaptasi dari instrumen yang dikembangkan oleh Cooke, Cavanagh, Hurst, \& Sparrow (2011). Skala ini digunakan setelah divalidasi oleh ahli dan dinyatakan valid, untuk kemudian diujicobakan tingkat keterbacaan item-item skala ini dan dilakukan perbaikan seperlunya.

Dalam penelitian ini, kecemasan matematika awal siswa tidak diukur. Hal ini dikarenakan siswa yang menjadi subjek penelitian berada pada taraf perkembangan yang sama. Selain itu, mereka juga belum mendapat perlakuan yang dapat mempengaruhi kecemasan matematikanya. Oleh karena itu, kecemasan matematika siswa kedua kelas diasumsikan secara umum tidak berbeda.

Data yang diperoleh dari pengukuran ini merupakan data interval. Akan tetapi, dalam hal ini disederhanakan menjadi skala dengan opsi jawaban sangat tidak setuju, tidak setuju, setuju, dan sangat setuju. Oleh karena itu, data tersebut harus ditransformasi terlebih dahulu menjadi data interval dengan menggunakan Method of Summated Ratings (Azwar, 2012).

Tahap selanjutnya adalah pengujian kesamaan rata-rata skor kecemasan matematika siswa pada kelas eksperimen dan kelas kontrol. Dalam penelitian ini, seluruh tahapan tersebut proses uji statistiknya menggunakan software SPSS 16. 


\section{HASIL DAN PEMBAHASAN}

Dalam penelitian ini data kecemasan matematika siswa diambil dan dianalisis setelah perlakuan diberikan. Hal ini dikarenakan hipotesis penelitian yang diuji adalah kecemasan matematika siswa SMP yang diberi perlakuan berupa CLGI lebih rendah dibandingkan dengan siswa yang diajar dengan pembelajaran konvesional. Pada tabel 1 berikut disajikan data skor kecemasan matematika pada kedua kelas.

Tabel 1. Data Skor Kecemasan Matematika Siswa Kelas CLGI dan Konvensional

\begin{tabular}{|c|c|c|c|c|c|c|}
\hline \multirow{2}{*}{ Kelas } & \multirow{2}{*}{$\mathbf{K M}$} & \multirow{2}{*}{$\mathbf{N}$} & \multicolumn{2}{|c|}{ Skor } & \multirow{2}{*}{ Rerata } & \multirow{2}{*}{$\begin{array}{c}\text { Simpangan } \\
\text { baku }\end{array}$} \\
\hline & & & Maks & Min & & \\
\hline \multirow{3}{*}{ CLGI } & Total & 36 & 67,00 & 24,00 & 44,97 & 10,04 \\
\hline & Belajar & 36 & 36,00 & 13,00 & 21,67 & 4,71 \\
\hline & Tes & 36 & 42,00 & 8,00 & 23,31 & 7,29 \\
\hline \multirow{3}{*}{ Konvensional } & Total & 45 & 71,00 & 23,00 & 45,13 & 10,38 \\
\hline & Belajar & 45 & 31,00 & 13,00 & 21,44 & 4,42 \\
\hline & Tes & 45 & 49,00 & 6,00 & 23,69 & 7,68 \\
\hline
\end{tabular}

Skor maksimum kecemasan matematika adalah 102, skor kecemasan matematika ketika siswa belajar di kelas matematika adalah 49, dan kecemasan matematika ketika siswa menghadapi tes matematika adalah 53.

Tabel 1 menunjukkan bahwa rerata skor kecemasan matematika siswa kelas CLGI sedikit lebih rendah dibanding kelas konvensional dengan selisih 0,16. Apabila ditinjau dari masing-masing aspek, baik kecemasan matematika ketika siswa belajar di kelas matematika maupun ketika menghadapi tes, kecemasan matematika siswa secara deskriptif relatif sama.

Berdasarkan klasifikasi pengukuran Psikologi yang diberikan Azwar (2012), baik secara keseluruhan maupun ditinjau dari masing-masing aspek, kecemasan matematika siswa kedua kelas masuk dalam kategori sedang. Ditinjau dari simpangan baku skor kecemasan matematika siswa kedua kelas, terlihat bahwa persebaran skor kecemasan matematika kedua kelas tampak relatif sama. Hal ini ditunjukkan oleh simpangan baku skor kecemasan matematika kelas CLGI yang tidak terlalu berbeda dengan kelas konvensional.

Untuk menguji hipotesis tersebut dalam penelitian ini digunakan uji kesamaan dua rata-rata. Uji kesamaan dua rata-rata berupa uji t digunakan apabila data skor kecemasan matematika pada kedua kelas memenuhi asumsi kenormalan dan homogen. Apabila asumsi normal tidak terpenuhi, digunakan uji U Mann-Whitney dan apabila asumsi homogen tidak terpenuhi digunakan uji t'. 
Untuk menguji normalitas data skor kecemasan matematika siswa pada kelas eksperimen dan kontrol digunakan uji Kolmogorov-Smirnov. Tabel 2 berikut menyajikan rangkuman uji normalitas data skor kecemasan matematika.

Tabel 2. Hasil Uji Normalitas Data Skor Kecemasan Matematika Kelas CLGI dan Kelas Konvensional

\begin{tabular}{clcccc}
\hline \multirow{2}{*}{$\begin{array}{c}\text { Kecemasan } \\
\text { Matematika }\end{array}$} & \multirow{2}{*}{ Kelas } & \multicolumn{2}{c}{$\begin{array}{c}\text { Kolmogorov- } \\
\text { Smirnov }\end{array}$} & \multirow{2}{*}{ Simpulan } & \multirow{2}{*}{ Keterangan } \\
\cline { 3 - 4 } & & Statistic & Sig. & & \\
\hline \multirow{2}{*}{ Total } & CLGI & 0,112 & 0,200 & $\mathrm{H}_{0}$ Diterima & Normal \\
& Konvensional & 0,105 & 0,200 & $\mathrm{H}_{0}$ Diterima & Normal \\
\multirow{2}{*}{ Belajar } & CLGI & 0,106 & 0,200 & $\mathrm{H}_{0}$ Diterima & Normal \\
& Konvensional & 0,140 & 0,027 & $\mathrm{H}_{0}$ Ditolak & Tidak Normal \\
\multirow{2}{*}{ Tes } & CLGI & 0,143 & 0,086 & $\mathrm{H}_{0}$ Diterima & Normal \\
& Konvensional & 0,092 & 0,200 & $\mathrm{H}_{0}$ Diterima & Normal \\
\hline
\end{tabular}

$\mathrm{H}_{0}$ : data sampel berasal dari populasi yang berdistribusi normal, $\alpha=0,05$.

Tabel 2 menunjukkan bahwa secara statistik data skor kecemasan matematika pada kedua kelas berasal dari populasi yang berdistribusi normal. Hal ini ditunjukkan oleh nilai signifikansi pada kelas CLGI $(0,200)$ dan kelas konvenional $(0,200)$ memenuhi kriteria penerimaan $\mathrm{H}_{0}$, yaitu nilai signifikansi tersebut lebih dari nilai $\alpha$. Data skor kecemasan matematika ketika siswa belajar di kelas CLGI berasal dari populasi yang berdistribusi normal, karena nilai signifikansi 0,200 lebih dari nilai $\alpha$, sedangkan pada kelas konvensional data sampel tidak berasal dari populasi yang berdistribusi normal, karena nilai signifikansi kurang dari nilai $\alpha$. Tabel 2 tersebut juga menunjukkan bahwa baik kelas CLGI maupun konvensional data skor kecemasan matematika siswa ketika tes matematika berasal dari populasi yang berdistribusi normal karena nilai signifikansinya yang juga lebih dari nilai $\alpha$.

Uji homogenitas dilakukan untuk mengetahui apakah secara statistik, varians data skor kecemasan matematika siswa pada kedua kelas berbeda atau tidak. Pada penelitian ini untuk menguji homogenitas digunakan uji Levene. Rangkuman uji statistiknya disajikan pada Tabel 3 berikut.

Tabel 3. Hasil Uji Homogenitas Varians Data Skor Kecemasan Matematika Kelas CLGI dan Konvensional

\begin{tabular}{ccccc}
\hline $\begin{array}{c}\text { Kecemasan } \\
\text { Matematika }\end{array}$ & Levene Statistic & Sig. & Simpulan & Keterangan \\
\hline Total & 0,219 & 0,641 & $\mathrm{H}_{0}$ Diterima & Homogen \\
Tes & 0,015 & 0,904 & $\mathrm{H}_{0}$ Diterima & Homogen \\
\hline $\mathrm{H}_{0}$ : varians kedua data sampel homogen, $\alpha=0,05$. & &
\end{tabular}


Tabel 3 tersebut menunjukkan bahwa secara statistik varians data kecemasan matematika siswa kedua kelas homogen. Hal ini disebabkan syarat $\mathrm{H}_{0}$ diterima telah terpenuhi, yaitu nilai signifikansi sebesar 0,641 yang lebih dari nilai $\alpha$. Sejalan dengan hal tersebut, data kecemasan matematika siswa ketika tes matematika pada kedua kelas juga homogen, karena nilai signifikansi 0,904 lebih dari nilai $\alpha$.

Berdasarkan data pada tabel 2 dan 3, untuk menguji kesamaan rata-rata data skor kecemasan matematika dan kecemasan matematika siswa ketika menghadapi tes matematika kelas eksperimen dan kontrol digunakan uji t. Hal ini dikarenakan asumsi kenormalan dan homogenitas telah terpenuhi. Untuk uji kesamaan rata-rata data kecemasan matematika ketika siswa belajar di kelas CLGI dan konvensional digunakan uji U Mann-Whitney, karena asumsi normal yang tidak terpenuhi. Rangkuman uji statistiknya disajikan pada Tabel 4, Tabel 5, dan Tabel 6 berikut.

Tabel 4. Hasil Uji Kesamaan Rata-rata Data Skor Kecemasan Matematika Kelas CLGI dan Kelas Konvensional

\begin{tabular}{ccccc}
\hline Selisih Rata-rata & $\mathbf{t}$ & Sig. (1 tailed) & $\boldsymbol{\alpha}$ & Simpulan \\
\hline$-0,16$ & $-0,070$ & 0,472 & 0,05 & $\mathrm{H}_{0}$ Diterima \\
\hline $\mathrm{H}_{0}:$ tidak terdapat perbedaan rata-rata skor kecemasan matematika kelas & CLGI dan konvensional \\
$\mathrm{H}_{1}:$ rata-rata skor kecemasan matematika siswa kelas CLGI lebih rendah daripada kelas konvensional
\end{tabular}

Tabel 4 menunjukkan bahwa tidak ada perbedaan yang signifikan antara ratarata skor kecemasan matematika siswa kelas CLGI $(44,97)$ dan kelas konvensional $(45,13)$. Hal ini dikarenakan syarat $\mathrm{H}_{0}$ ditolak tidak terpenuhi, yaitu nilai signifikansi sebesar 0,472 yang lebih dari nilai $\alpha$. Dengan kata lain, siswa kelas CLGI memiliki skor kecemasan matematika yang tidak lebih rendah dibandingkan siswa kelas konvensional.

Ditinjau dari aspek kecemasan matematika ketika siswa belajar di kelas, kecemasan siswa kedua kelas tidak menunjukkan adanya perbedaan yang signifikan. Hal ini ditunjukkan oleh hasil uji U Mann-Whitney pada tabel 5 berikut. Tabel 5 menunjukkan bahwa hipotesis penelitian ditolak karena nilai signifikasi sebesar 0,706 lebih dari nilai $\alpha=0,05$. Oleh karena itu, dapat disimpulkan bahwa kecemasan matematika siswa ketika belajar di kelas CLGI maupun kelas konvensional secara statistik tidak ada perbedaan. 
Tabel 5. Hasil Uji Kesamaan Rata-rata Data Skor Kecemasan Matematika Ketika Siswa Belajar di Kelas CLGI dan Kelas Konvensional

\begin{tabular}{cccc}
\hline $\mathbf{Z}$ & Sig. (2 tailed) & $\boldsymbol{\alpha}$ & $\mathbf{H}_{\mathbf{0}}$ \\
\hline$-0,377$ & 0,706 & 0,05 & Diterima \\
\hline
\end{tabular}

$\mathrm{H}_{0}$ : tidak terdapat perbedaan rata-rata skor kecemasan matematika siswa ktika belajar di kelas CLGI dan konvensional

Sementara itu, hasil uji t yang dilakukan menunjukkan bahwa ditinjau dari aspek kecemasan matematika siswa ketika tes pada siswa kedua kelas, secara statistik juga tidak menunjukkan perbedaan. Hasil uji t ini dapat dilihat pada tabel 6 berikut.

Tabel 6. Hasil Uji Kesamaan Rata-rata Data Skor Kecemasan Matematika Ketika Siswa Mengerjakan Tes

\begin{tabular}{ccccc}
\hline Selisih Rata-rata & $\mathbf{t}$ & Sig. (1 tailed) & $\boldsymbol{\alpha}$ & Simpulan \\
\hline$-0,39$ & $-0,220$ & 0,826 & 0,05 & $\mathrm{H}_{0}$ Diterima \\
\hline
\end{tabular}

$\mathrm{H}_{0}$ : tidak terdapat perbedaan rata-rata skor kecemasan matematika kelas CLGI dan konvensional

$\mathrm{H}_{1}$ : rata-rata skor kecemasan matematika siswa kelas CLGI lebih rendah daripada kelas konvensional

Selain skala kecemasan matematika, setiap setelah pembelajaran pada kedua kelas dilaksanakan, siswa diberikan jurnal untuk mengukur keadaan psikologis mereka terkait kecemasan dalam mengikuti pembelajaran matematika. Grafik fluktuasi rata-rata skor kecemasan matematika berdasarkan jurnal harian siswa kelas CLGI dan konvensional dapat dilihat pada Gambar 1 berikut.

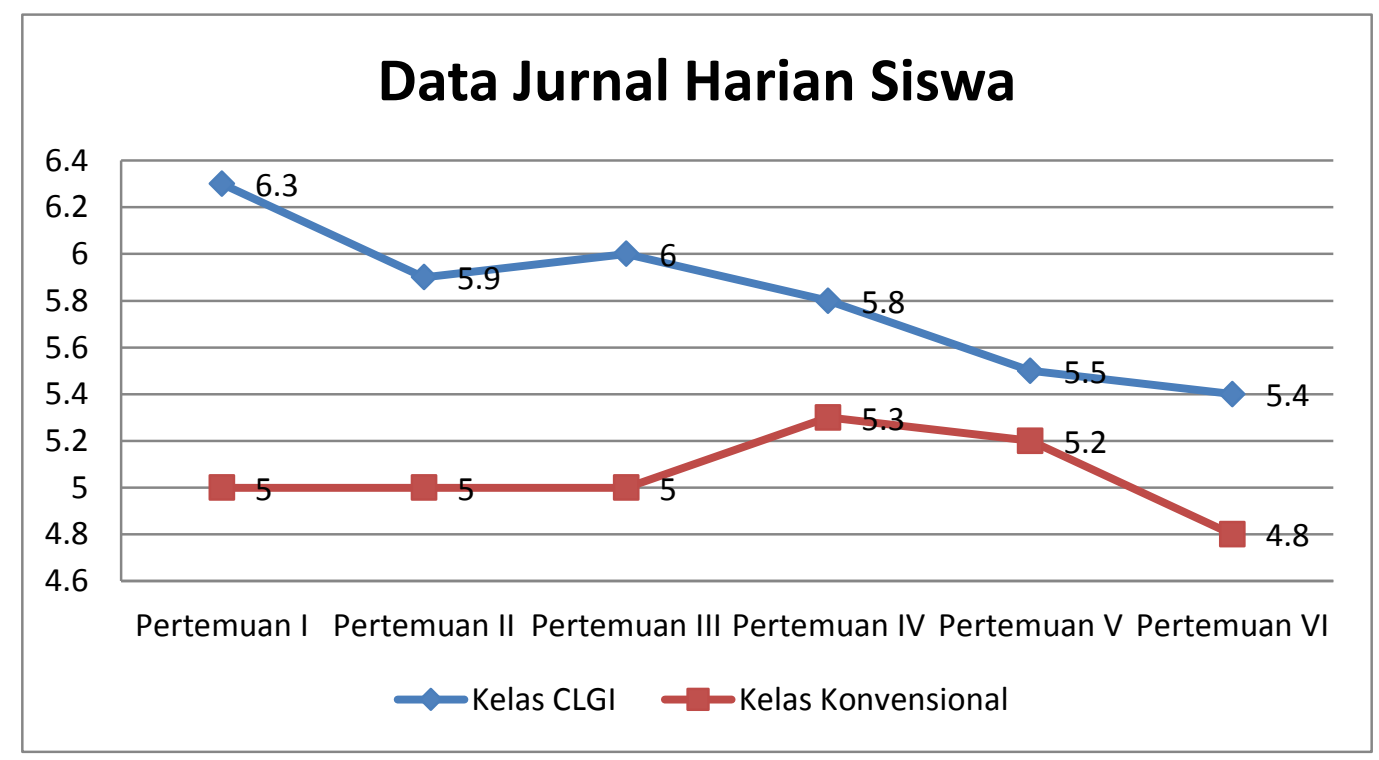

\section{Gambar 1. Grafik Skor Jurnal Harian Siswa}

Gambar 1 menunjukkan bahwa kecemasan matematika siswa kelas CLGI pada pertemuan pertama tampak lebih tinggi dibandingkan kelas konvensional. Dari hasil wawancara yang peneliti lakukan kepada beberapa siswa, diketahui bahwa mereka 
belum terbiasa dengan CLGI dan kaget menghadapi beban tugas yang harus mereka kerjakan. Namun, setelah para siswa di kelas eksperimen mulai memahami aktivitas pembelajaran dan tugas yang harus dikerjakan, kecemasan matematika siswa berangsurangsur menunjukkan penurunan. Kecemasan matematika siswa pada pertemuan ketiga menunjukkan sedikit peningkatan sebesar 0,1. Dari pengamatan peneliti, ada beberapa kelompok yang cenderung fokus pada tampilan bahan presentasi mereka, sehingga mereka kurang mendapat intisari dari kegiatan pembelajaran yang mereka lakukan. Hal ini menyebabkan siswa-siswa tersebut merasa pengetahuan yang mereka dapat masih kurang yang bermuara pada meningkatnya kecemasan matematika mereka. Berbeda dengan kelas CLGI yang menunjukkan tren penurunan, pada kelas konvensional kecemasan matematika siswa selama pembelajaran cenderung naik turun. Akan tetapi, secara umum kecemasan matematika siswa kelas konvensional sedikit lebih rendah dibandingkan kelas CLGI.

Dari hasil uji statistik, dapat disimpulkan bahwa tidak terdapat perbedaan yang signifikan antara kecemasan matematika siswa kelas CLGI dan kelas konvensional. Walaupun rata-rata skor kecemasan matematika siswa kelas CLGI $(44,97)$ lebih rendah dibandingkan rata-rata kelas konvensional $(45,13)$, tetapi hasil uji t menunjukkan bahwa nilai sig. (1 tailed) sebesar 0,472 belum memenuhi syarat penolakan $\mathrm{H}_{0}$. Hal ini dikarenakan nilai signifikansi tersebut lebih dari $\alpha=0,05$. Ditinjau dari klasifikasinya (Azwar, 2012), kecemasan matematika siswa pada kedua kelas secara rata-rata tergolong dalam kategori sedang. Apabila ditelaah dari masing-masing aspek, yaitu kecemasan siswa ketika belajar di kelas matematika dan kecemasan siswa tes juga menunjukkan hasil yang sama, yaitu tidak terdapat perbedaan rata-rata skor kecemasan matematika siswa pada kedua kelas. Lebih lanjut, pada masing-masing aspek tersebut kecemasan matematika siswa secara rata-rata juga tergolong dalam klasifikasi sedang.

Namun, hal tersebut bukan berarti bahwa CLGI tidak memberikan pengaruh terhadap kecemasan matematika siswa. Apabila ditinjau dari jurnal harian siswa, terlihat bahwa meskipun kecemasan siswa kelas CLGI pada awalnya lebih tinggi daripada kelas konvensional, tetapi kecemasan matematika siswa kelas CLGI menunjukkan tren penurunan yang kontinu. Kecemasan matematika siswa pada kelas CLGI pada awal 
pembelajaran tampak lebih tinggi jika dibandingkan dengan kelas konvensional maupun kelas CLGI pada pertemuan-pertemuan selanjutnya. Hal ini dikarenakan CLGI merupakan pembelajaran baru bagi siswa. Mereka belum terbiasa dengan pembelajaran ini beserta tugas dan aktivitas penyelidikan dan pemecahan masalah yang harus dilakukan. Para siswa merasa kaget dengan beban tugas yang harus dilaksanakan. Setelah mereka cukup memahami, merasakan manfaat, dan beradaptasi dengan pembelajaran ini, kecemasan matematika siswa pun berangsur-angsur menurun.

Walaupun demikian, kecemasan siswa pada pertemuan ketiga menunjukkan sedikit peningkatan dibandingkan pertemuan sebelumnya. Dari pengamatan peneliti, ada beberapa kelompok yang cenderung fokus pada tampilan bahan presentasi mereka, sehingga mereka kurang mendapat intisari dari kegiatan pembelajaran yang mereka lakukan. Hal ini menyebabkan siswa-siswa tersebut merasa pengetahuan yang mereka dapat masih kurang yang bermuara pada meningkatnya kecemasan matematika mereka. Namun, secara umum kecemasan matematika siswa kelas CLGI menunjukkan tren penurunan bila dibandingkan dengan kelas konvensional.

Akan tetapi, rata-rata skor kecemasan matematika siswa kelas CLGI tidak berbeda secara signifikan dibandingkan dengan siswa kelas konvensional. Hasil tersebut sejalan dengan hasil penelitian yang dilakukan oleh Yuliana (2013) yang mengkaji pengaruh pendekatan Different Instruction (DI). Ia menemukan bahwa pembelajaran DI tidak cukup berarti mempengaruhi kecemasan matematika siswa. Hasil tersebut juga didukung pernyataan Suryanto (2008) yang menyatakan bahwa kecemasan matematika merupakan aspek afektif hasil akumulasi pembelajaran Matematika sejak jenjang sekolah dasar. Hal in berarti kecemasan ini merupakan buah dari pengalaman belajar apriori yang terakumulasi pada diri siswa yang menyebabkan dibutuhkan waktu yang lebih lama untuk mereduksinya. Apalagi mengingat perlakuan pada kelas CLGI hanya dilaksanakan selama tujuh pertemuan. Namun, tidak menutup kemungkinan tidak adanya perbedaan kecemasan matematika siswa pada kedua kelas disebabkan karena siswa kelas CLGI masih beradaptasi dengan pembelajaran, aktivitas, dan beban tugas yang terkandung di dalam pembelajaran CLGI. Oleh karena itu, CLGI lebih 
memberikan manfaat bagi siswa dibandingkan dengan pembelajaran konvensional, ditinjau dari tren penurunan kecemasan matematika siswa.

\section{KESIMPULAN}

Kecemasan matematika siswa SMP yang diajar dengan CLGI tidak lebih rendah daripada yang diajar dengan pembelajaran konvensional. Lebih lanjut, baik secara keseluruhan maupun ditinjau dari masing-masing aspek, kecemasan matematika siswa yang diajar dengan kedua pembelajaran ini tergolong dalam klasifikasi sedang. Bagi peneliti lain yang akan mengkaji pengaruh CLGI terhadap kecemasan matematika, agar lebih memperhatikan lama pelaksanaan penelitian. Hal ini dikarenakan waktu pemberian perlakuan yang hanya tujuh kali pertemuan, belum cukup untuk mengurangi kecemasan matematika secara signifikan. Dalam hal ini, siswa masih memerlukan waktu lebih untuk beradaptasi dengan CLGI dan beban tugas serta aktivitas yang harus mereka laksanakan. Selain itu, apabila kegiatan pembelajaran melibatkan hands on activity, harus diberikan penekanan kepada siswa bahwa mereka harus lebih fokus pada inti atau maksud dari kegiatan tersebut dilakukan, bukan pada keindahan tampilan bahan presentasi yang mereka buat.

\section{DAFTAR PUSTAKA}

Azwar, S. (2012). Sikap Manusia: Teori dan Pengukurannya. Edisi ke 2. Yogyakarta: Pustaka Pelajar.

Cooke, A., Cavanagh, R., Hurst, C., \& Sparrow, L. (2011). Situasional Effects of Mathematics Anxiety in Pre-service Teacher Education. Paper Presented at 2011 AARE International Research in Education Conference, Melbourne, Australia.

Erdogan, A., Kesici, S., \& Sahin I. (2011). Prediction of High School Students' Mathematics Anxiety by Their Achievement Motivation and Social Comparison. Elementary Education Online, 10 (2), 646-652.

Gleason, J. (2008). Relationship between Pre-service Elementary Teachers' Mathematics Anxiety and Content Knowledge for Teaching. Journal of Mathematics Science and Mathematics Education, 3, (1), 39- 47.

Herman, T. (2005). Mengajar dan Belajar Matematika dengan Pemahaman. Januari 26, 2013. http://file.upi.edu/Direktori/D\%20\%20FPMIPA/JUR.\%20PEND.\%20MATEMATIKAA/196210111991011\%20$\%$ 20TATANG\%20HERMAN/Artikel/Artikel13.pdf.

Karimi A. \& Venkatesan S. (2009). Mathematics Anxiety, Mathematics Performance and Academic Hardiness in High School Students. International Journal of Education and Science, 1 (1), 33-37. 
Khatoon, T. \& Mahmood, S. (2010). Mathematics Anxiety among Secondary School Students in India and its Relationship to Achievement in Mathematics. European Journal of Social Science, 16 (1), 75-86.

Lyons, I. M. \& Beilock, S. L. (2012). When Math Hurts: Math Anxiety Predicts Pain Network Activation in Anticipation of Doing Math. PlosOne, 7 (10), 1-6.

Ma, X. (2003). Effect of Early Acceleration of Students in Mathematics on Attitude toward Mathematics and Mathematics Anxiety. Teachers College Record, 105 (3), 438-464.

Meece, J.L., Wigfiled, A., \& Eccles J.S. (1990). Predictors of Math Anxiety and Its Influence on Young Adolescents' Course Enrollment Intentions and Performance in Mathematics. Journal of Educational Psychology, 82 (1), 60-70.

Sherman, B.F. \& Wither, D.P. (2003). Mathematics Anxiety and Mathematics Achievement. Mathematics Education Research Journal, 15 (2), 138-150.

Suryanto. (2008). Aspek Afektif Hasil Pembelajaran Matematika. Paedagogia, 11 (1), 62-73.

Woodard, T. (2004). The Effect of Math Anxiety on Post-Secondary Development Students as Related to Achievement, Gender, and Age. Inquiri, 6, (1).

Yandi, B.D. (2013). Kecemasan Matematika (Mathematics Anxiety). Oktober 20, 2013. http://edukasi.kompasiana.com/2013/02/22/kecemasan-matematika-mathematicanxiety-536046.html.

Yuliana, N. (2013). Pengaruh Pendekatan Different Instruction (DI) terhadap Kemampuan Pemahaman, Penalaran, dan Kecemasan Matematika (Math Anxiety). Tesis. Universitas Pendidikan Indonesia Bandung: Tidak Diterbitkan.

Zakaria, E. \& Nordin, N.M. (2008). The Effect of Mathematics Anxiety on Matriculation Students as Related to Motivation and Achievement. Eurasia Journal of Mathematics, Science \& Technology Education, 4 (1), 27-30. 